\title{
FORMULASI KEBIJAKAN PEMERINTAH TENTANG PEMBENTUKAN BADAN USAHA MILIK DAERAH (BUMD) PERSEROAN TERBATAS (PT) MASS RAPID TRANSIT (MRT) JAKARTA DI PROVINSI DKI JAKARTA
}

\author{
Antik Bintari, S.IP., MT \\ Landrikus Hartarto Sampe Pandiangan \\ Departemen Ilmu Pemerintahan FISIP \\ Universitas Padjadjaran \\ e-mail : antikisw@gmail.com
}

\begin{abstract}
ABSTRAK
Penelitian ini bertujuan untuk mendeskripsikan dan menganalisis formulasi kebijakan pada Peraturan Daerah Nomor 7 Tahun 2013 Tentang Perubahan Atas Peraturan Daerah Nomor 3 Tahun 2008 Tentang Pembentukan BUMD PT MRT Jakarta. Metode yang digunakan adalah deskriptif dengan pendekatan kualitatif. Hasil penelitian menunjukkan bahwa ada 4 tahapan formulasi yang dilakukan sehingga menghasilkan kebijakan pembentukan BUMD PT MRT Jakarta yaitu perumusan masalah, penyusunan agenda, pemilihan alternatif kebijakan untuk memecahkan masalah dan tahap penetapan kebijakan. Pengambilan keputusan yang lambat mengenai pembangunan MRT telah memberikan pengaruh pada pembentukan PT MRT Jakarta. Pertarungan kepentingan yang terjadi antar berbagai aktor membuat tahapan perumusan kebijakan berjalan lambat. Proses yang kurang berjalan dengan baik membuat penanganan kemacetan berjalan lambat dan tidak kunjung selesai.

Kata Kunci: Formulasi Kebijakan Publik, Mass Rapid Transit Jakarta, Pembentukan BUMD PT MRT Jakarta

ABSTRACT

This study purpose to describe and analyze the formulation of policy on Local Regulation No. 7 of 2013 on Amendment Regional Regulation No. 3 of 2008 on the establishment of Regional Owned Enterprises PT MRT Jakarta. The method used is descriptive qualitative approach. The results showed that there are four stages of formulation do so result in policy formation PT MRT Jakarta, namely the formulation of the problem, setting the agenda, election of policy alternatives to solve the problem and stage setting policy. Slow decision making regarding the development of MRT has an impact on the establishment of PT MRT Jakarta. Conflict of interests among different actors make the stages of policy formulation is slow. The process is not run by either making the handling of bottlenecks slow and protracted.
\end{abstract}

Keywords: Public Policy Formulation, Mass Rapid Transit Jakarta, The Establishment of PT MRT Jakarta 


\section{PENDAHULUAN}

Keadaan dewasa ini banyak negara berkembang sedang mengalami permasalahan transportasi dan beberapa diantaranya sudah berada dalam tahap sangat kritis. Hal tersebut dialami kota Jakarta sebagai Ibukota Negara Kesatuan Republik Indonesia, dimana sedang melakukan pembenahan sistem transportasi. Memiliki beragam fungsi seperti pemerintahan negara dan provinsi, perdagangan, industri, jasa, pendidikan dan budaya tidak serta merta menjadi pekerjaan yang mudah bagi Provinsi ini.

Pertumbuhan penduduk dan pemakaian kendaraaan pribadi yang tinggi sangat berbanding terbalik dengan pertumbuhan prasarana jalan. Kondisi angkutan umum yang buruk juga membuat masyarakat lebih tertarik menggunakan kendaraan pribadi. Kurangnya daya tampung jalan membuat pergerakan kendaraan tidak dapat berjalan normal. Kemacetan tidak terhindarkan dan membutuhkan penanganan serius dari seluruh stakeholder yang berkepentingan.

Hasil Study on Integrated Transportation Master Plan (SITRAMP) oleh JICA/Bappenas menunjukkan, bahwa jika sampai tahun 2020 tidak ada perbaikan yang dilakukan pada sistem transportasi Jabodetabek (Jakarta, Bogor, Depok, Tangerang dan Bekasi), maka estimasi kerugian ekonomi yang terjadi sebesar Rp. 28,1 Trilliun dan kerugian nilai waktu perjalanan yang mencapai 36,9 Trilliun. Berbagai program pengendalian kemacetan seperti pengadaan Bus Transjakarta dan APTB, pelarangan sepeda motor di jalan tertentu, pemberlakukan 3 in 1 terlihat belum membuahkan hasil. Pilihan pembangunan moda transportasi Mass Rapid Transit (MRT) pun menjadi sangat ditunggu masyarakat dalam upaya pengentasan kemacetan.

Provinsi DKI Jakarta memerlukan waktu sampai 24 tahun untuk merencanakan, menganalisis dan mengeksekusi program tersebut. Hal ini menjadi pertanyaan besar, dimana ketika dari tahun ke tahun dihadapkan pada persoalan kemacetan yang semakin parah, namun pelaksanaan solusi kebijakan yang dibuat khususnya pada program MRT ini menghabiskan waktu yang sangat lama.

Dalam perjalanannya, gejolak muncul ketika Pemerintah memutuskan untuk membentuk satu badan khusus yang menjadi operator pelaksanaan MRT Jakarta. Pilihan pembentukan BUMD PT MRT Jakarta sebagai pengelola MRT menjadi pembicaraan hangat di kalangan masyarakat. Pembentukan PT MRT Jakarta dinilai masih kurang perlu dilakukan, mengingat saat ini telah ada sejumlah organisasi yang mengurusi pelayanan publik bidang transportasi di Provinsi DKI Jakarta. Sebut saja seperti Satuan Kerja Perangkat Daerah (SKPD), Badan Layanan Umum daerah (BLUD) dan PT Kereta Api 
Indonesia (KAI) yang khusus mengelola bidang perkeretaapian.

Dinas Perhubungan dan Transportasi sebagai bagian SKPD yang mengelola bidang perhubungan, telah memiliki sejumlah organisasi teknis yang difungsikan untuk mengelola transportasi publik seperti Unit Pengelola dan Unit Pengelola Teknis. Contoh nya pada transportasi sejenis Light Rail Transit (LRT), dimana dikelola oleh Unit Pengelola yang langsung dibawah tanggung jawab Dinas Perhubungan dan Transportasi. Saat ini, Indonesia juga mempunyai operator khusus yang mengelola bidang perkeretaapian yakni PT Kereta Api Indonesia (KAI). Dengan keberadaan PT KAI, sebenarnya kebutuhan mendirikan operator baru bidang perkeretaapian di Provinsi DKI Jakarta menjadi kurang perlu. Pemberian langsung wewenang kepada PT KAI dalam mengurus MRT Jakarta akan lebih cepat dan banyak manfaatnya daripada harus mendirikan operator baru, dikarenakan menghabiskan waktu dan proses yang lama.

Pilihan membentuk operator baru dengan label BUMD bersifat Perseroan Terbatas menjadi kurang relevan dengan semangat mewujudkan pelayanan fasilitas publik MRT. Stigma yang berkembang di masyarakat menunjukkan ketidakpuasan akan kinerja pengelolaan BUMD yang bersifat PT, karena cenderung mengutamakan sisi keuntungan atau aspek bisnis perusahaan daripada perwujudan pelayanan bagi masyarakat. Berkaca dari pengelolaan transportasi Bus Transjakarta yang telah berubah dari sebelumnya Badan Layanan Umum Daerah menjadi PT Transjakarta, ternyata tidak memberikan perubahan yang lebih baik dari sisi pelayanan pada masyarakat Jakarta. Sejumlah persoalan kurang baiknya manajemen dan pelayanan, telah menimbulkan rasa pesimis akan kehadiran operator baru PT MRT Jakarta.

Pengalaman selama ini, Badan Usaha Milik Daerah selalu menghadapi dua sisi berlawanan. Satu sisi, tujuan membentuk BUMD adalah sebagai sumber keuangan daerah guna meningkatkan kemampuan dan kekuatan daerah dalam menyelenggarakan urusan daerah. Sementara di sisi lain, BUMD diharapkan dapat menjadi alat Pemerintah Daerah dalam melaksanakan pelayanan fasilitas publik bagi masyarakat. Fakta di lapangan menunjukkan bahwa tujuan dibentuknya BUMD pengelola transportasi publik di Provinsi DKI Jakarta belum secara nyata diwujudkan. Baik dari sisi meningkatkan pemasukan daerah, maupun melaksanakan pelayanan fasilitas publik bagi masyarakat. Publik berhak mendapat kejelasan dibalik dibentuknya BUMD PT MRT Jakarta, apakah melayani kepentingan publik atau untuk tujuan peningkatan penerimaan daerah semata. 
Untuk penelitian terkait yang sudah pernah dilakukan tentang masalah ini belum ada. Hal ini dikarenakan pembentukan dan operasionalisasi BUMD PT MRT Jakarta yang masih terhitung baru. Sejauh ini penelitian yang banyak dilakukan adalah mengenai pembentukan dan operasionalisasi PT Transjakarta. Seperti diketahui, bahwa PT Transportasi Jakarta selaku pelaksana operasional pada tahun 2016 ini telah memasuki tahun ke - 12 dalam pengelolaan Bus Transjakarta.

\section{TINJAUAN PUSTAKA}

\section{Formulasi Kebijakan Publik}

Perumusan kebijakan merupakan merupakan salah satu tahap yang penting dalam pembentukan kebijakan publik. Seperti yang ditulis oleh Charles Lindblom dan beberapa ahli yang lain, dalam memahami proses perumusan kebijakan kita perlu memahami aktor - aktor yang terlibat atau pemeran serta dalam proses pembentukan kebijakan tersebut, baik aktor - aktor yang resmi maupun aktor - aktor yang tidak resmi. Seperti yang diungkapkan oleh Charles Lindblom, bahwa untuk memahami siapa sebenarnya yang merumuskan kebijakan lebih dahulu harus dipahami sifat - sifat semua pemeran serta (partisipants), bagian atau peran apa yang mereka lakukan, wewenang atau bentuk kekuasaan yang mereka miliki, dan bagaimana mereka saling berhubungan serta saling mengawasi. Dari berbagai jenis pemeran serta, masing - masing pemeran serta ini menurut Lindblom mempunyai peran secara khusus yang meliputi: warganegara biasa, pemimpin organisasi, anggota DPR, pemimpin lembaga legislatif, aktivis partai, pemimpin partai, hakim, pegawai sipil, ahli teknik, dan manajer dunia usaha.

Studi mengenai formulasi kebijakan memberikan perhatian yang sangat dalam pada sifat - sifat (perumusan) permasalahan publik. Karena (perumusan) permasalahan publik merupakan fundamen besar dalam merumuskan kebijakan publik sehingga arahnya menjadi benar, tepat dan sesuai. Perumusan masalah menurut William Dunn (1999:26), akan sangat membantu para analis kebijakan untuk menemukan asumsi - asumsi yang tersembunyi, mendiagnosis penyebagian penyebagian masalah publik, memetakan tujuan - tujuan yang memungkinkan, memadukan pandangan - pandangan yang berseberangan/bertentangan, dan merancang peluang - peluang kebijakan yang baru. Formulasi kebijakan akan berkaitan dengan beberapa hal yaitu cara bagaimana suatu masalah, terutama masalah publik memperoleh perhatian dari para pembuat kebijakan, cara bagaimana merumuskan usulanusulan untuk menganggapi masalah tertentu yang timbul, cara bagaimana memilih salah satu alternatif untuk mengatasi masalah publik. 


\section{Tahapan Formulasi Kebijakan Publik}

a. Perumusan Masalah

Mengenali dan merumuskan masalah merupakan langkah yang paling fundamental dalam perumusan kebijakan. Untuk dapat merumuskan kebijakan dengan baik, maka masalah - masalah publik harus dikenali dan didefenisikan dengan baik pula. Kebijakan publik pada dasarnya dibuat untuk memecahkan masalah yang ada dalam masyarakat. Oleh karena itu, seberapa besar kontribusi yang diberikan oleh kebijakan publik dalam menyelesaikan masalah masalah dalam masyarakat menjadi pertanyaan yang menarik dalam evaluasi kebijakan publik. Namun demikian, apakah pemecahan masalah tersebut memuaskan atau tidak bergantung pada ketepatan masalah - masalah publik tersebut dirumuskan. Rushefky secara eksplisit menyatakan bahwa kita sering gagal menemukan pemecahan masalah yang tepat dibandingkan menemukan masalah yang tepat.

\section{b. Agenda Kebijakan}

Tidak semua masalah publik akan masuk ke dalam agenda kebijakan. Masalah - masalah tersebut saling berkompetisi antara satu dengan yang lain. Hanya masalah - masalah tertentu yang pada akhirnya akan masuk ke dalam agenda kebijakan. Suatu masalah untuk masuk ke dalam agenda kebijakan harus memenuhi syarat syarat tertentu, seperti misalnya apakah masalah tersebut mempunyai dampak yang besar bagi masyarakat dan membutuhkan penanganan yang harus segera dilakukan?. Pada fase ini pemerintah berupaya menyusun sejumlah agenda penting yang perlu dibahas dan selanjutnya dijadikan materi pokok perumusan kebijakan publik. Agenda yang disusun pemerintah menyangkut beberapa masalah pokok yaitu masalah rutinitas pemerintah, masalah dari masyarakat dan masalah baru dari masyarakat.Masalah publik yang telah masuk ke dalam agenda kebijakan akan dibahas oleh para perumus kebijakan, seperti kalangan legislatif (DPR), kalangan eksekutif (Presiden dan para pembantunya), agen - agen pemerintah dan mungkin juga kalangan yudikatif. Masalah masalah tersebut dibahas berdasarkan tingkat urgensinya untuk segera diselesaikan.

\section{c. Pemilihan Kebijakan \\ Alternatif Memecahkan Masalah \\ Setelah masalah - masalah} publik didefenisikan dengan baik dan para perumus kebijakan sepakat untuk memasukkan masalah tersebut ke dalam agenda kebijakan, maka langkah selanjutnya adalah membuat pemecahan masalah. Disini para perumus kebijakan akan berhadapan dengan alternatif - alternatif kebijakan yang dapat diambil untuk memecahkan masalah tersebut. Pada tahap ini para perumus kebijakan akan dihadapkan pada pertarungan kepentingan antar berbagai aktor 
yang terlibat dalam perumusan kebijakan. Dalam kondisi seperti ini, maka pilihan - pilihan kebijakan akan didasarkan pada kompromi dan negosiasi yang terjadi antar aktor yang berkepentingan dalam pembuatan kebijakan.

\section{d. Tahap}

Penetapan

\section{Kebijakan}

Setelah salah satu dari sekian alternatif kebijakan diputuskan diambil sebagai cara untuk memecahkan masalah kebijakan, maka tahap paling akhir dalam pembentukan kebijakan adalah menetapkan kebijakan yang dipilih tersebut sehingga mempunyai kekuatan hukum yang mengikat. Alternatif kebijakan yang diambil pada dasarnya merupakan kompromi dari berbagai kelompok kepentingan yang terlibat dalam pembentukan kebijakan tersebut. Penetapan kebijakan dapat berbentuk berupa undang - undang, yurisprudensi, keputusan presiden, keputusan keputusan menteri dan lain sebagainya.

\section{Perencanaan Transportasi}

Perlu disadari bahwa kajian perencanaan transportasi mempunyai ciri yang berbeda dengan kajian bidang lain. Hal ini disebabkan karena objek penelitian suatu kajian perencanaan transportasi cukup luas dan beragam. Disamping itu, kaijan perencanaan transportasi juga biasanya melibatkan aspek yang cukup banyak dan beragam pula. Secara singkat, ciri kajian perencanaan transportasi ditandai dengan adanya multimoda, multidisiplin, multisektoral, dan multimasalah. Multimoda. kajian perencanaan transportasi selalu melibatkan lebih dari satu moda transportasi sebagai bahan kajian. Hal ini mudah dimengerti mengingat objek dasar kajian perencanaan transportasi adalah pergerakan manusia, dan/atau barang, yang pasti melibatkan banyak moda transportasi. Tambahan lain, Indonesia dikenal sebagai negara yang terdiri dari ribuan pulau sehingga pergerakan dari suatu tempat asal ke tempat tujuan sangat tidak mungkin hanya menggunakan satu modal saja. Tidaklah mengherankan bahwa Sistem Transportasi Nasional (Sistranas) yang kita miliki mempunyai konsep utama, yaitu konsep sistem transportasi integrasi antarmoda.

Kalaupun kajian yang dimaksud difokuskan pada daerah tertentu, misalnya terminal bus atau bandara, aspek multimoda akan selalu timbul ke permukaan. Perencana transportasi, bagaimana pun, harus memperhatikan adanya interaksi antara pergerakan internal di dalam daerah kajian (misalnya terminal bus atau bandara) dengan pergerakan eksternalnya. Artinya, harus diperhatikan adanya moda transportasi lain selain bus (untuk terminal bus) atau pesawat udara (untuk bandara).

Multidisiplin. Kajian perencanaan transportasi melibatkan banyak disiplin keilmuan karena 
aspek kajiannya sangat beragam, mulai dari ciri pergerakan, pengguna jasa, sampai dengan sistem prasarana ataupun sarana transportasi itu sendiri. Tentu saja dalam pelaksanaannya, semua aspek kajian tersebut harus dapat diantisipasi. Kajian perencanaan transportasi biasanya melibatkan bidang keilmuan seperti rekayasa, ekonomi, geografi, penelitian operasional, sosial politik, matematika, informatika, dan psikologi.

\section{Multisektoral.}

Yang

dimaksud dengan multisektoral disini adalah banyaknya lembaga, atau pihak terkait yang berkepentingan dengan kajian perencanaan transportasi. Kajian perencanaan transportasi biasanya melibatkan beberapa lembaga pemerintah ataupun swasta yang masing-masing mempunyai kepentingan yang berbeda sehingga diperlukan koordinasi dan penanganan yang baik. Untuk kasus perencanaan terminal bus antarkota seperti contoh di atas misalnya, lembaga pemerintah atau pun swasta yang terkait meliputi DLLAJ, BPN, Dinas Tata Kota, polantas, operator bus, Dinas Pendapatan Daerah, dan lain lain. Multimasalah. Karena kajian perencanaan transportasi merupakan kajian multimoda, multidisiplin, dan multisektoral, tentu saja menimbulkan multi masalah, permasalahan yang dihadapi mempunyai dimensi yang cukup beragam dan luas, mulai dari yang berkaitan dengan aspek pengguna jasa, rekayasa, operasional, ekonomi, sampai dengan aspek sosial.

Meskipun terdapat perbedaan antara kota-kota di berbagai negara, pergerakan di dalam daerah perkotaan mempunyai beberapa ciri yang sama yang berlaku hampir pada semua kota kecil dan kota besar di dunia. Ciri ini merupakan prinsip dasar yang merupakan titik tolak kajian transportasi. Ciri ini juga mendefenisikan konsep yang digunakan oleh para perencana angkutan dan perekayasa untuk memahami dan mempelajari pergerakan.

Pada pelaksanaan perencanaan transportasi diperlukan suatu pendekatan sistem. Pendekatan sistem adalah pendekatan umum untuk suatu perencanaan atau teknik dengan menganalisis semua faktor yang berhubungan dengan permasalahan yang ada. Contohnya, kemacetan lokal yang disebabkan oleh penyempitan lebar jalan dapat dipecahkan dengan melakukan perbaikan secara lokal. Akan tetapi, hal ini mungkin menyebabkan permasalahan berikutnya yang timbul di tempat lain. Pendekatan sistem akan dapat mengaitkan permasalahan yang ada, misalnya apakah permasalahan tersebut disebabkan karena terlalu banyaknya lalulintas di daerah tersebut? Jika memang demikian, pertanyaan berikutnya adalah mengapa lalu lintas tersebut terlalu banyak? Jawabannya mungkin karena terlalu banyak kantor yang sangat berdekatan letaknya, atau mungkin 
juga karena ruang gerak yang sangat sempit bagi pergerakan lalu lintas. Pemecahannya dapat berupa manajemen lalu lintas secara lokal, pembangunan jalan baru, peningkatan pelayanan angkutan umum, atau perencanaan tata guna lahan yang baru. Pendekatan sistem mencoba menghasilkan pemecahan yang terbaik dari beberapa alternatif pemecahan yang ada, tentunya dengan batasan tertentu (waktu dan biaya). Untuk lebih memahami dan mendapatkan alternatif pemecahan masalah yang terbaik, perlu dilakukan pendekatan secara sistem - sistem transportasi dijelaskan dalam bentuk sistem transportasi makro yang terdiri dari beberapa sistem transportasi mikro. Sistem transportasi secara menyeluruh (makro) dapat dipecahkan menjadi beberapa sistem yang lebih kecil (mikro) yang masing - masing saling terkait dan saling mempengaruhi seperti terlihat pada gambar dibawah ini.

Gambar 2.3 Sistem Transportasi Makro

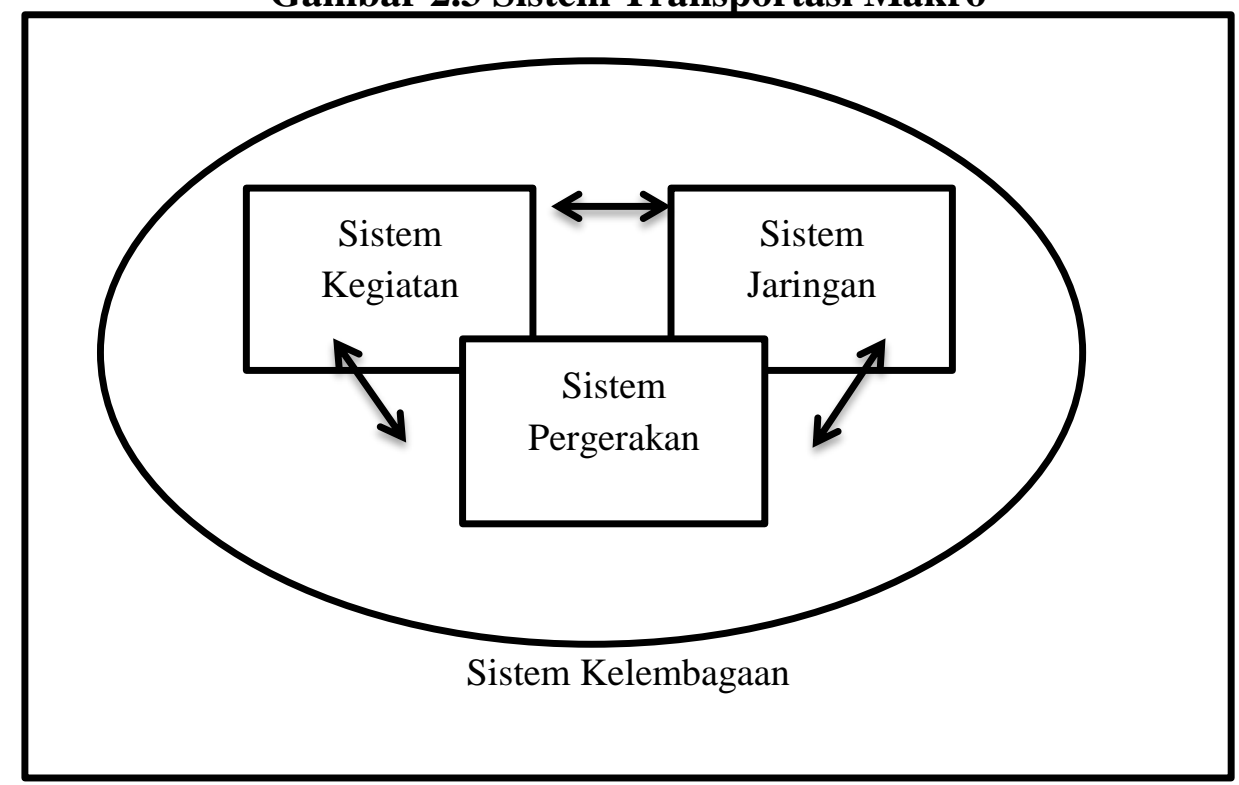

Sumber: Tamin (1992b, 1993a, 1994b, 1995hjk)

Sistem transportasi mikro tersebut terdiri dari: a) sistem kegiatan; b) sistem jaringan prasarana transportasi; c) sistem pergerakan lalu lintas; dan d) sistem kelembagaan. Sistem kegiatan, sistem jaringan, dan sistem pergerakan akan saling mempengaruhi seperti terlihat pada gambar diatas. Perubahan pada sistem kegiatan jelas akan mempengaruhi sistem jaringan melalui perubahan pada tingkat pelayanan pada sistem pergerakan. Begitu juga perubahan pada sistem jaringan akan dapat mempengaruhi sistem kegiatan melalui peningkatan mobilitas dan aksesibilitas dari sistem pergerakan tersebut.Selain itu, sistem pergerakan memegang 
peranan penting dalam menampung pergerakan agar tercipta pergerakan yang lancar yang akhirnya juga pasti mempengaruhi kembali sistem kegiatan dan sistem jaringan yang ada dalam bentuk aksesibilitas dan mobilitas. Ketiga sistem mikro ini saling berinteraksi dalam sistem transportasi makro.

\section{METODE PENELITIAN}

Tulisan ini membahas bagaimana pelaksanaan formulasi kebijakan Pemerintah Provinsi DKI Jakarta dalam mengatasi kemacetan, mulai dari perencanaan pembangunan moda transportasi massal Mass Rapid Transit (MRT) sampai pada pembentukan Badan Usaha Milik Daerah (BUMD) Perseroan Terbatas (PT) MRT Jakarta.

Metode yang digunakan dalam penelitian studi ini bersifat deskriptif kualitatif dengan menggunakan data primer dan sekunder. Dengan menggunakan desain penelitian deskriptif, nantinya akan dapat menguraikan serta menggambarkan keadaan sebenarnya di Provinsi DKI Jakarta yang akan diteliti secara sistematis, faktual dan akurat mengenai fakta dan hubungan yang akan diteliti.

Teknik pengumpulan data dilakukan melalui studi pustaka dan studi lapangan. Studi pustaka dilaksanakan dengan mencari berbagai literatur dari berbagai sumber berkaitan dengan pengambilan kebijakan dalam bidang moda transportasi Mass Rapid
Transit (MRT). Studi lapangan meliputi observasi, wawancara dan dokumentasi. Setelah pengumpulan data, kemudian dilakukan aktivitas analisis data berupa reduksi data, penyajian data dan penarikan kesimpulan atau verifikasi.

Data primer tentang perumusan kebijakan pembangunan moda transportasi MRT Jakarta dan pembentukan BUMD PT MRT Jakarta diambil dari beberapa instansi yakni Dinas Perhubungan dan Transportasi, Badan Perencanaan dan Pembangunan Daerah, Dewan Perwakilan Rakyat Daerah, Dewan Transportasi Kota Jakarta dan PT MRT Jakarta. Adapun data sekunder diambil dari berbagai literatur, jurnal dan buku mengenai transportasi.

Setelah data dikumpulkan dari lapangan, kemudian diolah dan dianalisis dengan menggunakan teori tahapan formulasi kebijakan oleh William Dunn yaitu perumusan masalah, agenda kebijakan, pemilihan alternatif kebijakan untuk memecahkan masalah, dan tahapan penetapan kebijakan.

\section{PEMBAHASAN}

Formulasi Kebijakan Pada Peraturan Daerah Nomor 7 Tahun 2013 Tentang Perubahan Atas Peraturan Daerah Nomor 3 Tahun 2008 Tentang Pembentukan BUMD PT MRT Jakarta

\section{Perumusan Masalah}

Mengenali dan merumuskan masalah merupakan langkah yang paling fundamental dalam 
perumusan kebijakan. Untuk dapat merumuskan kebijakan dengan baik, maka masalah - masalah publik harus didefenisikan dengan baik pula. Terwujudnya formulasi kebijakan Peraturan Daerah Nomor 7 Tahun 2013 Tentang Perubahan Atas Peraturan Daerah Nomor 3 Tahun 2008 Tentang Pembentukan BUMD PT MRT Jakarta, tidak terlepas dari permasalahan perhubungan yaitu semakin tingginya tingkat kemacetan yang terjadi setiap hari. Peran wilayah Provinsi DKI Jakarta dalam memainkan berbagai fungsi seperti pusat pemerintahan negara dan provinsi, perdagangan, industri, jasa, pendidikan, rekreasi, hiburan dan kebudayaan membuat permasalahan kemacetan tidak dapat lagi terhindarkan. Tingkat pertumbuhan ekonomi yang cukup tinggi di wilayah Provinsi DKI Jakarta memang telah menarik arus urbanisasi yang tinggi.

Permasalahan klasik lalu lintas berupa ketidakseimbangan antara supply prasarana dengan demand lalu lintas, beban lalu lintas yang tinggi pada ruas - ruas jalan utama disebabkan pula oleh terakumulasinya perjalanan penduduk ke/dari berbagai aktivitas kota yang berbeda pada waktu yang relatif bersamaan.Jaringan jalan yang tersedia tidak sanggup lagi untuk menampung tingkat pertumbuhan kendaraan bermotor yang sangat tinggi. Berdasarkan data Dinas Perhubungan dan Transportasi DKI Jakarta, tercatat bahwa supply berupa jaringan jalan terdiri dari panjang jalan sebanyak $6690 \mathrm{~km}=41,68 \mathrm{~km}$, Road Ratio sebesar 6, 3 \% dari luas wilayah DKI Jakarta dan pertumbuhan panjang jalan $+0,01$ $\% /$ Thn. Adapun untuk demand terbagi atas 3 bagian. Pertama, kebutuhan perjalanan yaitu 25,7 Juta perjalanan/hari (Jabodetabek), 74,7 $\%$ menggunakan kendaraan pribadi dan 25,3\% menggunakan angkutan umum. Kedua mengenai jumlah kendaraan bermotor yaitu +10 juta unit yang terdiri dari kendaraan pribadi 9,9 juta $(98,9 \%)$ dan kendaraan umum 112 ribu (1,1\%). Ketiga terkait dengan modal share terdiri dari menggunakan kendaraan pribadi $74,7 \%$ dan menggunakan angkutan umum 25,3 \%. Jumlah keseluruhan biaya kemacetan yang dihasilkan diperkirakan $\mathrm{Rp} \quad 45,2$ Trilyun/tahun, terdiri dari pemborosan BBM, biaya operasional kendaraan, time value, economic value dan pencemaran energi.

Dinas Perhubungan dan Transportasi DKI Jakarta selaku dinas terkait yang mengurusi pelayanan bidang perhubungan dan transportasi, dalam Rencana Strategis tahun 2013 - 2017 telah mengidentifikasi isu - isu strategis terkait permasalahan transportasi, yaitu:

1) Kapasitas jalan sudah tidak mencukupi untuk memenuhi pergerakan orang dan barang yang terus meningkat dari dalam kota maupun dari luar kota Jakarta;

2) Terbatasnya ketersediaan dan pelayanan angkutan umum 
menyebabkan masih tingginya penggunaan kendaraan pribadi;

3) Sistem dan jaringan transportasi multimoda belum terintegrasi dengan baik menyebabkan tidak efisien dan efektifnya mobilitas penduduk;

4) Ketersediaan prasarana jalan dan akses untuk mendukung Pelabuhan Tanjung Priok dan Bandar Udara Soekarno Hatta tidak memadai untuk melayani pergerakan orang dan barang;

5) Ketersediaan dan pelayanan transportasi laut ke wilayah Kepulauan Seribu masih terbatas untuk melayani pergerakan orang dan barang sehingga mengurangi aksesibilitas dan konektivitas dengan Kota Jakarta;

6) Rendahnya tingkat kedisplinan masyarakat dalam berlalu lintas;

7) Pengembangan transportasi darat yang aman, tertib, terintegrasi dan terjangkau;

8) Pengembangan transportasi laut, dengan standar internasional dengan memanfaatkan keunggulan teknologi serta pengembangan wilayah;

9) Pengembangan transportasi udara, dengan standar internasional serta untuk pengembangan wilayah;

10) Pengembangan sistem pelayanan yang efisien dengan pelayanan prima.

\section{Agenda Kebijakan}

Pada dasarnya tidak semua masalah publik akan masuk ke dalam agenda kebijakan. Adapun masalah - masalah tersebut saling berkompetisi antara satu dengan yang lain. Hanya masalah - masalah tertentu yang pada akhirnya masuk ke dalam agenda kebijakan. Salah satu syarat agar suatu masalah masuk kedalam agenda kebijakan adalah masalah tersebut mempunyai dampak yang besar bagi masyarakat dan membutuhkan penanganan yang harus segera dilakukan. Melihat kondisi transportasi di wilayah DKI Jakarta yang memiliki banyak permasalahan, maka sudah selayaknya mendapat perhatian dari Pemerintah Provinsi, karena kalau tidak diatasi dengan segera maka akan dapat menganggu jalannya aktivitas di berbagai aspek kehidupan lainnya seperti jalannya roda pemerintahan, perdagangan, bisnis, pariwisata dan budaya.

Sesuai dengan apa yang diungkapkan oleh Dunn pada tahapan agenda kebijakan, bahwa pada fase ini pemerintah berupaya menyusun sejumlah agenda penting yang perlu dibahas dan selanjutnya dijadikan materi pokok perumusan kebijakan publik. Berdasarkan pengamatan di lapangan, penulis melihat bahwa penyusunan agenda kebijakan sudah berjalan dengan baik. Pemerintah Provinsi DKI Jakarta telah memprioritaskan penanganan permasalahan kemacetan dan kemudian meletakkan strategi pengembangan sistem transportasi pada agenda prioritas pertama di sejumlah agenda kebijakan Pemerintah Provinsi. Dalam dokumen Rencana 
Pembangunan Jangka Panjang

Daerah (RJPD) Tahun 2005 - 2025,

Rencana Pembangunan Jangka

Menengah Daerah (RPJMD) Tahun 2013 - 2017 yang diatur dalam Peraturan Daerah Nomor 2 Tahun 2013, dan sebagai penjabaran tahunan terhadap RPJMD Daerah dihasilkan Rencana Kerja Pemerintah Daerah (RKPD) setiap tahunnya, tercantum bahwa salah satu yang menjadi agenda prioritas Pemerintah Provinsi adalah terkait pengembangan sistem transportasi.

Pemerintah Provinsi DKI Jakarta selanjutnya telah mampu menghasilkan suatu Grand Design penanganan permasalahan kemacetan yakni dengan melahirkan Road Map Pola Transportasi Makro. Grand Design Pola Transportasi Makro terdiri dari 3 bagian besar yakni pertama berupa pengembangan angkutan massal yang diantaranya MRT/Subway+KA, LRT/Monorail, BRT/Busway. Kedua adalah pembatasan lalu lintas diantaranya pembatasan penggunaan kendaraan bermotor, Road Pricing/ERP, pembatasan parkir, fasilitas park and ride. Ketiga adalah peningkatan kapasitas jaringan diantaranya Intelligent Transportation System (ITS), pelebaran jalan/FO/UP, pengembangan jaringan jalan dan pedestrianisasi. Bahwa disadari betul dalam upaya menyelesaikan permasalahan kemacetan di DKI Jakarta, tidak bisa hanya menyelesaikan suatu bagian dari permasalahan, melainkan harus saling terintegrasi dan bersifat makro. Hal tersebut dibuktikan dengan adanya tiga kerangka besar dari Pola Transportasi Makro yakni pengembangan angkutan massal, pembatasan lalu lintas dan juga peningkatan kapasitas jaringan. Diharapkan dalam kerangka waktu hingga tahun 2020, pelaksanaan pola transportasi makro dapat berjalan dengan baik sesuai waktu yang telah ditentukan.

\section{Pemilihan Alternatif Untuk Memecahkan Masalah}

Setelah perumusan masalah dan penyusunan agenda selesai dilaksanakan, maka selanjutnya dilakukan pemilihan alternatif kebijakan untuk memecahkan masalah kemacetan yang terjadi. Untuk dapat menyeimbangkan antara kebutuhan (demand) dan persediaan (supply) haruslah memperhatikan sistem transportasi berkelanjutan.

$$
\text { Perencanaan pembangunan }
$$

moda transportasi massal MRT sudah direncanakan berikut dengan pelaksanaan kajian nya mulai tahun 1980 - an. Tetapi keadaan berbicara lain, para pengambil kebijakan belum memprioritaskan pengembangan angkutan massal seperti Kereta Api dan justru lebih mengutamakan pembangunan jalan untuk mengakomodir keberadaan angkutan pribadi. Perdebatan pengembangan angkutan massal dengan roda atau rel menjadi perbincangan yang hangat bagi para pengambil kebijakan baik di lingkungan Pemerintah Pusat 
maupun di Pemerintah Provinsi DKI Jakarta.

Hasil temuan penulis di lapangan menunjukkan ada beberapa faktor yang membuat perencanaan pembangunan MRT Jakarta memakan waktu hingga 24 tahun sebelum groundbreaking dilaksanakan. Tarik menarik kepentingan disinyalir sangat kuat terjadi. Pengaruh dari berbagai kepentingan mewarnai perjalanan perencanaan pembangunan moda transportasi ini. Meskipun tidak ada bukti konkret yang menjelaskan keterkaitan antara pengambil kebijakan dengan kelompok kepentingan seperti pengusaha otomotif yang dikabarkan tidak menginginkan keberadaan pembangunan MRT, tetapi sejumlah pernyataan dari beberapa informan mengindikasikan hal tersebut benar terjadi.

Keberlangsungan perencanaan dan pembangunan proyek moda transportasi MRT sangat tergantung pada kemauan politik (political will) dan koordinasi yang terjadi dari seluruh elemen yang terkait dengan pemangku kepentingan dalam proyek MRT.

Sesuai dari pernyataan Pak Eko Haryanto selaku Kepala Sub Bagian Keuangan Unit Pengelola Kereta Api Ringan/LRT Dinas Perhubungan dan Transportasi Provinsi DKI Jakarta , beliau menyatakan:

"Terkait dengan pengaruh pabrikan mobil yang sebagian besar dikuasai oleh pengusaha Jepang, asumsi saya pasti kesitu. Karena ini strategi bisnis Jepang juga. Sekarang yang ngasih modal MRT siapa? Jepang. Mungkin dari tahun sekian ke tahun sekian dia ngumpulin devisa dari Indonesia dibawa kesana. Sekarang kan nyerah lah Indonesia, tapi pakai produk Jepang juga akhirnya. Asumsi saya sudah lama seperti itu. Ini permainan juga. Sekarang gini logikanya aja, kalau dulu mindsetnya pemerintah memprioritaskan transportasi massal, kenapa jalan tol atau jalan layang non tol yang ada di wilayah Jakarta gak dibikin jalur MRT. Kenapa tol Jakarta Outer Ring Road gak dibikin angkutan massal saja disitu. Tekanannya dari siapa? Ya pasti untuk mengakomodir pengguna kendaraan pribadi kan. Produsen pengguna kendaraan terbesar kan mereka."

Kedua terkait dengan masalah anggaran. Berbicara keterbatasan anggaran yang dijadikan sebagai faktor terlambatnya pembangunan moda transportasi MRT cenderung merupakan permasalahan yang umumnya dihadapi oleh berbagai sektor pembangunan, akan tetapi melihat jumlah Anggaran Pendapatan Belanja Daerah (APBD) Provinsi DKI Jakarta yang sangat besar, seharusnya tidak menjadi 
kendala yang sulit dalam hal penganggaran pembangunan moda transportasi massal seperti MRT. Hampir setiap tahun, nilai APBD Pemerintah Provinsi DKI Jakarta terus mengalami kenaikan. Tercatat mulai dari tahun 2001 berjumlah 8,2 Trilliun, mengalami kenaikan rata rata sebesar 2 trilliun setiap tahunnya hingga tahun 2007. Sempat turun di angka 20, 4 trilliun pada tahun 2008, selanjutnya mengalami kenaikan di angka 4-5 trilliun setiap tahunnya hingga mencapai angka 72 Trilliun Rupiah pada tahun anggaran 2014.

Realitas yang terjadi, adapun biaya yang dikeluarkan untuk membangun moda transportasi massal MRT adalah berasal dari pinjaman yang diberikan oleh Badan Kerjasama Internasional Jepang (JICA) terhadap Pemerintah Indonesia. Kalau akhirnya memang akan meminjam dana untuk biaya pembangunan, kenapa tidak dari dulu saja langsung dipinjam kalau memang kendala yang dinaikkan ke permukaan adalah mengenai pembiayaan proyek. Kerugian akibat kemacetan yang terjadi bukan saja berimbas pada kerugian ekonomi semata melainkan sudah merambah aspek kesehatan, lingkungan dan aspek lainnya. Pemerintah daerah selalu membelanjakan anggaran untuk mengatasi kemacetan, namun sejauh ini menemui jalan buntu. Begitu besar nya biaya yang dikeluarkan untuk proyek pembangunan mahal seperti simpang susun (fly over), jalan lingkar (ring road), dan jalan tol dalam kota, yang telah membuat perjalanan mobil pribadi semakin menarik sehingga timbul beban lalu lintas yang baru. Meskipun secara nominal biaya pembangunan MRT tinggi, seharusnya demi kepentingan masyarakat luas dapat dicari jalan keluar yang win - win solution, sehingga akibat yang ditimbulkan tidak terjadi seperti sekarang ini.

Jika ada niat dan kemauan dalam menyelesaikan permasalahan kemacetan, seharusnya pengalokasian anggaran daerah dapat dilakukan lebih cermat dan proporsional. Dengan nilai APBD yang hampir setiap tahunnya meningkat, rasanya tidak terlalu sulit untuk menyisihkan sebagian anggaran pemerintah daerah terhadap kelanjutan pembiayaan pembangunan MRT saat itu. Provinsi DKI Jakarta dalam membangun moda transportasi MRT menggunakan pinjaman yang diberikan kepada Pemerintah Pusat oleh Badan Kerjasama Internasional Jepang (JICA). Pinjaman tersebut diatur secara khusus melalui Peraturan Pemerintah Nomor 10 tahun 2011 mengenai Prosedur Pengadaan Pinjaman Asing dan Penerimaan Hibah. Pemerintah Pusat setuju untuk menerima kewajiban sebesar $49 \%$ pelunasan pinjaman dan menyediakannya kepada DKI melalui hibah. Sisa $51 \%$ nya diharapkan dipinjamkan kepada DKI dengan ketentuan yang sama dengan yang diterima Pemerintah Pusat dari JICA. Dana pinjaman akan dikembalikan dengan bunga 0,2\% 
dan $0,4 \%$ dengan jangka waktu pengembalian 30 tahun plus 10 tahun.

Dalam upaya mewujudkan kehadiran sistem MRT, kemudian dibentuk operator pengelola bernama PT Mass Rapid Transit (MRT) Jakarta. PT MRT Jakarta didirikan berdasarkan rekomendasi studi dari JBIC dan telah disetujui dalam kesepakatan antara JBIC dan Pemerintah Indonesia. Hasil temuan penulis di lapangan menunjukkan ada beberapa faktor yang menjadi pertimbangan Pemerintah Daerah dan DPRD DKI Jakarta dalam membentuk operator khusus pengelola MRT Jakarta.

Penulis kemudian meminta konfirmasi kepada pemangku kepentingan terkait pembentukan PT MRT Jakarta. Pak Triwisaksana selaku Ketua Badan Legislasi Daerah Tahun 2009 - 2014 sekaligus Wakil Ketua DPRD DKI Jakarta Tahun 2014-2019 menyatakan:

"Ada beberapa alasan kenapa kemudian PT MRT Jakarta diputuskan untuk dibentuk. Pertama, terkait skema pembiayaan. Amanah dari Pemerintah Jepang khususnya dari lembaga JICA agar ini adalah unit perusahaan bukan dari pemerintahan sehingga tidak bisa dibentuk semacam BLUD atau unit pengelola semacam itu. Harus berbentuk PT tapi bisa dimiliki oleh pemerintah. Solusinya adalah BUMD.
Kedua, sumber daya. Kalau berbentuk PT kan lebih fleksibel, tidak harus mengikuti skema birokrasi ataupun pegawai negeri sipil. Ketiga, operasional. Nantinya akan jauh lebih leluasa apabila dibandingkan sebagai organ pemerintah murni."

Alasan pertimbangan dalam pembentukan BUMD ini memang harus secara jelas diketahui agar tidak menimbulkan polemik di masyarakat. Keberadaan PT MRT Jakarta sebagai pengelola fasilitas publik memang tidak lepas dari pertanyaan. Pendapat yang berkembang mengatakan bahwa jika sebuah organisasi berbentuk Pereseroan Terbatas (PT) diberikan kewenangan mengelola fasilitas publik, maka kecenderungannya akan profit oriented dan menimbulkan kekhawatiran jika pembebanan biaya tarif ditujukan bagi masyarakat.

Menanggapi hal tersebut, pandangan berbeda disampaikan oleh Pak Triwisaksana selaku Ketua Badan Legislasi tahun 2009-2014 sekaligus Wakil Ketua DPRD DKI Jakarta tahun 2014-2019 yang menyatakan:

"Itu juga hal yang sama ketika membangun jaringan kereta rel melalui PT KAI. Jadi disatu sisi mereka harus profit, di sisi lain harus terjangkau tarifnya. Makanya itu dijembatani oleh skema 
yang disebut Public Service Obligation (PSO). Demikian juga dengan PT MRT nanti. Untuk tarif pasti disepakati antara PT MRT dengan Pemprov dan DPRD DKI. Kalau tarif dibawah nilai ekonomis kan sudah barang tentu harus ada subsidi. Subsidi itu diwujudkan dalam PSO. Kedua, PT MRT diberikan keleluasaan untuk mencari pendapatan selain tarif yaitu pengembangan properti disekitar stasiun tersebut dan sebagainya."

Penulis melihat bahwa realitas yang terjadi di lapangan dengan apa yang dikemukakan oleh Dunn pada tahapan pemilihan alternatif kebijakan untuk memecahkan masalah menjadi sangat relevan. Dunn mengatakan bahwa pada tahap pemilihan alternatif kebijakan untuk memecahkan masalah, para perumus kebijakan akan dihadapkan pada pertarungan kepentingan antar berbagai aktor yang terlibat dalam perumusan kebijakan.

Berdasarkan

hasil pengamatan, proses menghabiskan waktu lama pada formulasi kebijakan mengatasi persoalan kemacetan terjadi pada saat memilih alternatif kebijakan pembangunan moda transportasi MRT. Terjadinya tarik menarik kepentingan dan berbagai alasan seperti kurangnya kemauan politik dan mahalnya anggaran pembangunan membuat proses perencanaan pembangunan sangat lama.

Adapun pada saat memutuskan untuk memilih membentuk operator PT MRT Jakarta tidak menemui hambatan yang serius. Adanya amanat dari peraturan perundang - undangan yang memberikan ruang untuk memberikan izin kepada BUMD sebagai operator transportasi publik menjadi faktor utama. Alasan lainnya adalah berdasarkan perjanjian antara Pemerintah Indonesia dengan lembaga pemberi dana yang mengharuskan dibentuknya satu organisasi khusus pengelola MRT dan juga keinginan untuk lebih mengoptimalisasikan kinerja perusahaan dari aspek operasional dan sumber daya.

\section{Tahap Penetapan Kebijakan}

Pada tahapan yang terakhir dalam proses formulasi kebijakan sesuai dengan teori formulasi kebijakan menurut Wiliam Dunn adalah mengenai penetapan ataupun pengesahan kebijakan. Tahapan penetapan dan pengesahan kebijakan perlu dilakukan agar suatu kebijakan yang telah dipilih pada tahap sebelumnya pemilihan alternatif kebijakan, nantinya mempunyai kekuatan hukum yang mengikat dan tidak dapat diganggu gugat serta sesuai dengan proses peraturan perundang - undangan yang berlaku.

Setelah melalui perjalanan panjang, dengan melakukan kegiatan pembahasan melalui rapat kerja komisi - komisi dengan eksekutif 
maupun rapat - rapat fraksi, kemudian rapat dengar pendapat dengan beberapa stakeholder terkait, juga penyusunan draft rancangan peraturan daerah, selanjutnya Badan Legislatif Daerah (Balegda) menyampaikan finalisasi draft dalam Rapat Paripurna untuk kemudian dilakukan penetapan dan pengesahan menjadi Peraturan Daerah oleh DPRD dan Gubernur Provinsi DKI Jakarta.

Pengesahan kebijakan dilakukan pada 2 Peraturan Daerah. Pertama, Peraturan Daerah Nomor 3 Tahun 2008 tentang Pembentukan BUMD PT MRT Jakarta. PT MRT Jakarta resmi berdiri pada tanggal 17 Juni 2008 setelah mendapat persetujuan dari DPRD dan Pemerintah Provinsi. Kedua, pada Peraturan Daerah Nomor 7 Tahun 2013 tentang perubahan atas Peraturan Daerah Nomor 3 Tahun 2008 Tentang Pembentukan BUMD PT MRT Jakarta. Dengan peraturan sebelumnya direvisi, maka modal Perseroan PT MRT Jakarta resmi berubah dari nilai sebelumnya 200 Milyar menjadi 14, 6 Trilliun Rupiah.

\section{SIMPULAN}

DAN

\section{REKOMENDASI}

\section{Simpulan}

Pada tahapan formulasi kebijakan, langkah fundamental yang harus dilakukan menurut William Dunn adalah masalah publik harus dikenali dan dirumuskan. Pada pelaksanaannya, pengenalan dan perumusan permasalahan transportasi di DKI Jakarta secara umum sudah berjalan dengan cukup baik. Hal itu ditandai dengan telah adanya identifikasi isu strategis masalah perhubungan dan juga beberapa penelitian tentang transportasi Jakarta yang sebagian besar disusun oleh institusi Pemerintah Pusat dan daerah serta lembaga studi transportasi.

$$
\text { Pada pelaksanaannya, }
$$

Pemerintah Provinsi DKI Jakarta telah meletakkan isu kemacetan sebagai agenda prioritas pada RPJP Tahun 2005 - 2025, RPJMD Tahun 2013 - 2017 dan RKPD Tahunan. Adapun turunan dari hal tersebut, kemudian telah dihasilkan suatu grand design penanganan permasalahan kemacetan yakni Road Map Pola Transportasi Makro (PTM) dengan payung hukum yakni Peraturan Gubernur Nomor 103 tahun 2007 Tentang Pola Transportasi Makro.

Proses dan waktu yang cukup lama terjadi pada saat hendak memutuskan untuk memilih pembangunan Mass Rapid Transit (MRT). Terjadinya tarik menarik kepentingan berbagai stakeholder dan alasan seperti kurangnya kemauan politik dan mahalnya anggaran pembangunan membuat proses perencanaan pembangunan sangat lama. Sedangkan untuk proses perencanaan pembentukan operator PT MRT Jakarta tidak menemui hambatan yang serius. Adanya amanat dari peraturan perundang undangan yang memberikan ruang untuk memberikan izin kepada 
BUMD sebagai operator transportasi publik menjadi faktor yang utama dan diikuti keinginan untuk lebih mengoptimalisasikan kinerja perusahaan dari aspek operasional dan sumber daya.

Pemerintah Daerah bersama dengan DPRD Provinsi DKI Jakarta melaksanakan formulasi dan menghasilkan kebijakan yakni Peraturan Daerah Nomor 7 Tahun 2013 Tentang Perubahan Atas Peraturan Daerah Nomor 3 Tahun 2008 Tentang Pembentukan Badan Usaha Milik Daerah (BUMD) Perseroan Terbatas (PT) Mass Rapid Transit (MRT) Jakarta.

\section{Rekomendasi}

Pelaksanaan perumusan masalah sebaiknya melalui satu pintu dan dilakukan secara berkesinambungan dan terukur. Seringkali yang terjadi di beberapa instansi pemerintahan di Indonesia, pengumpulan data mengenai suatu permasalahan hanya menjadi tugas formalitas dan dilaksanakan dengan seadanya saja. Padahal dalam suatu pengambilan keputusan, yang menjadi titik vital adalah mengenai ketersediaan dan tingkat akurasi data yang dihasilkan. Dengan data yang telah valid dan diperbaharui secara berkala, resiko kesalahan dalam pengambilan kebijakan dapat dihindarkan dengan seminimal mungkin.

Melihat apa yang menjadi isi dari Pola Transportasi Makro, ada satu hal yang kurang menurut penulis yaitu hendaknya memperhatikan kepentingan stakeholder angkutan umum yang dikelola oleh pengusaha swasta. Penulis melihat ini menjadi penting agar nantinya harapan terciptanya sistem angkutan massal berjalan dengan baik apakah itu yang dikelola oleh badan Pemerintah maupun pengusaha swasta. Juga penting kedepannya agar terwujud sistem transportasi yang saling mendukung dan terintegrasi satu sama lain.

Eksekusi percepatan pembangunan moda transportasi massal menjadi kekurangan Pemerintah Provinsi DKI Jakarta selama ini. Kurangnya langkah antisipatif membuat efek negatif yaitu kemacetan tidak terhindarkan lagi. Adanya kemauan politik yang mengutamakan kepentingan masyarakat banyak menjadi hal yang penting diperbaiki kedepannya. Anggaran APBD yang jumlahnya sangat besar sebaiknya dialokasikan dengan lebih cermat lagi ke sektorsektor yang lebih membutuhkan untuk dibenahi. Hal ini menjadi mutlak dipenuhi agar harapan terwujudnya sistem transportasi yang berkelanjutan dapat terlaksana.

$$
\text { Perlunya memperhatikan }
$$

ketentuan dalam pembentukan peraturan daerah yakni aspek keterbukaan dan asas kejelasan rumusan. Hal ini dirasa penulis menjadi bagian yang penting agar proses pembentukan Peraturan Daerah seperti perencanaan, persiapan, penyusunan dan/atau dalam pembahasan Rancangan Peraturan Daerah benar - benar 
merupakan hasil perumusan bukan saja hanya antara pihak eksekutif dan legislatif saja, melainkan kesepakatan dari berbagai pihak terutama masyarakat.

\section{DAFTAR PUSTAKA}

Winarno, Budi. 2012. Kebijakan Publik, Teori, Proses, dan Studi Kasus.

Yogyakarta: CAPS

Agustinus, Leo. 2012. Dasar-Dasar Kebijakan Publik. Bandung: Penerbit Alfabeta

Dunn, William N. 2003. Pengantar Analisis Kebijakan Publik. Yogyakarta: Gadjah Mada University Press

Hamdi, Muchlis, 2014, Kebijakan Publik: Proses, Analisis, dan Partisipasi: Bogor: Ghalia Indonesia

Lubis, Solly. 2007. Kebijakan Publik. Bandung: Mandar Maju

Nugroho, Rian. 2003. Kebijakan Publik Formulasi, Implementasi, dan Evaluasi. Jakarta: Elex Media Komputindo

Moleong, Lexy J. 2005. Metode Penelitian Kualitatif.

Bandung: Remaja Rosda

Tamin, O.Z. 1997a. Perencanaan dan Pemodelan Transportasi, Edisi 1,Bandung:

\section{Penerbit ITB}

Tamin, O.Z. 2000. Perencanaan dan Pemodelan Transportasi. Bandung: Penerbit ITB

Surbakti, Ramlan, 1992, Memahami Ilmu Politik, Jakarta: Gramedia Widya Pustaka Utama

http://www.suarakarya.id/2015/10/03 /taktik-mengadu\%E2\%80\%88chinajepang.html (Diakses pada tanggal 27 Juni 2016 Pukul 10.17 Wib) http://slidehot.com/resources/kerjasa ma-jepang-indonesia-dari-zamanpenjajahan-hinggasekarang.1987567/ (Diakses pada tanggal 2 Juli 2016 Pukul 09.32 Wib) http://www.merdeka.com/uang/kisah -lobi-jepang-di-industri-mobilri.html (Diakses pada tanggal 2 Juli 2016 Pukul 09.36 Wib) http://www.gaikindo.or.id/perkemba ngan/ (Diakses pada tanggal 4 Juli 2016 Pukul 13.15 Wib)

https://m.tempo.co/read/news/2015/0 8/15/090692131/kereta-cepatjepang-dan-cina-berebut-proyek-bag1/2 (Diakses pada tanggal 4 Juli 2016 Pukul 13. 17 Wib)

http://koran.bisnis.com/read/2016012 2/250/512039/diplomasi-investasibila-poros-bergeser-ke-china (Diakses pada tanggal 4 Juli 2016 Pukul 13. $20 \quad$ Wib 